\title{
Analisis Kesehatan Daging dan Offals Babi yang Diproduksi Rumah Pemotongan Hewan Denpasar
}

\section{(THE ANALYSIS OF PORK AND OFFALS HEALTH PRODUCTED IN DENPASAR SLAUGHTER HOUSE)}

\author{
Ida Bagus Ngurah Swacita ${ }^{1 *}$, I Ketut Suada ${ }^{1}, K_{\text {Ketut Budiasa }}^{2}$, \\ Ida Ayu Resmihariningsih ${ }^{3}$ \\ ${ }^{1}$ Laboratorium Kesehatan Masyarakat Veteriner, Fakultas Kedokteran Hewan Universitas \\ Udayana, Jalan PB. Sudirman, Denpasar, Bali; \\ ${ }^{2}$ Laboratorium Fisiologi dan Farmasi Veteriner, Fakultas Kedokteran Hewan Universitas \\ Udayana, Jalan PB. Sudirman, Denpasar, Bali; \\ ${ }^{3}$ Mahasiswa Program Profesi Dokter Hewan, Fakultas Kedokteran Hewan Universitas \\ Udayana, Jalan PB. Sudirman, Denpasar, Bali. \\ *Email: ngurah.swacita@gmail.com
}

\begin{abstract}
Abstrak
Aspek keamanan pangan asal hewan perlu mendapat perhatian khusus karena penyakit yang menyerang manusia hampir $75 \%$ disebabkan oleh agen infeksi yang berasal dari hewan atau produk hewan. Tujuan penelitian ini adalah untuk menganalisis kesehatan daging dan jeroan babi produksi RPH yang berpotensi menularkan penyakit zoonosis pada manusia. Penelitian ini menggunakan metode survei eksploratif kualitatif yaitu menganalisis kesehatan daging dan jeroan babi yang diperiksa secara inspeksi, palpasi, dan incici berdasarkan perbedaan jenis kelamin (jantan dan betina) dan umur hewan (muda dan dewasa) dengan total sampel yang diperiksa masing-masing sebanyak 100 sampel. Hasil penelitian menunjukkan, seluruh daging babi tidak ditemukan kelainan atau sehat. Paru babi ditemukan nekrosis $15 \%$, pneumoni $30 \%$, kombinasi hemoragi dan pneumoni $5 \%$. Jantung babi ditemukan $13 \%$ hipertrofi/hiperplasi, dan pada hati babi ditemukan $1 \%$ mengandung larva sistiserkosis.Persentase kerusakan pada betina dewasa lebih tinggidibandingkan jantan dewasa. Dapat disimpulkan bahwa daging babi produksi RPH Pesanggaran masih layak dikonsumsi, namun sebagian kecil (5-30\%) jeroannya menunjukkan perubahan/kelainan yang berpotensi menularkan penyakit zoonosis pada manusia.
\end{abstract}

Kata kunci: Kesehatan daging; organ babi, RPH, zoonosis

\begin{abstract}
Food safety aspects of animal origin need special attention because the new diseases that attack humans are almost $75 \%$ caused by infectious agents that come from animals or animal products. The purpose of this study was to analyze the health of pork and offals (innards) by slaughterhouse production, which potentially transmits zoonotic disease in humans. This research used a qualitative explorative survey method that analyzed the health of pig meat and offals inspected by inspection, palpation, and incision based on sex difference (male and female) and animal age (young and adult) with total samples examined each of 100 samples. The results of this study indicate that pork is examined in Pesanggaran abattoir all healthy, pulmonary organs show necrosis $15 \%$ (9\% adult females/AF and $6 \%$ adult males/AM), $30 \%$ pneumonia (22\% AF and $8 \% \mathrm{AM}$ ), hemorrhage and pneumonia 5\% (4\% AF and 1\% AM), in the heart organ 13\% showed hypertrophy/hyperplasia (7\% AF and $6 \% \mathrm{AM}$ ), and $1 \%$ of the liver (AM) had cysticercosis. It can be concluded that pork slaughterhouse production in Pesanggaran is all healthy and only a small part of the offals (5-30\%) shows abnormalities that have the potential to transmit zoonotic diseases to humans.
\end{abstract}

Keywords: Pork; offals; health, slaughterhouse; zoonosis 


\section{PENDAHULUAN}

Menurut WHO (2005), sekitar 75\% penyakit-penyakit baru yang menyerang manusia dalam dua dasa warsa terakhir disebabkan oleh agen infeksi yang berasal dari hewan atau produk hewan, sehingga pangan asal hewan lebih berpotensi berbahaya jika dibandingkan dengan pangan asal nabati. Oleh sebab itu aspek keamanan pangan asal hewan perlu mendapat perhatian khusus. Ada beberapa penyakit yang dapat ditularkan lewat daging (meat borne disease) yang dianggap oleh WHO berbahaya untuk kesehatan manusia antara lain Fascioliasis (Pilet et al., 2010; Sripa et al., 2010), Sistiserkosis (Dharmawan et al., 2012; Swacita et al., 2015), dan Toxoplasmosis (Agustina et al., 2017; Damriyasa et al, 2000 a,b; Tenter et al., 2000).

Daging yang beredar di pasaran harus memenuhi syarat kesehatan dan keamanan (Hadiwiyoto, 1993, Direktorat Kesmavet, 2005). Oleh karena itu, dalam matarantai peredaran daging, harus mendapat pengawasan yang ketat mulai dari tempat pemotongan sampai ke konsumen. Di negara maju, jeroan seperti paru, hati, dan jantung tidak layak dikonsumsi dan disebut dengan istilah jeroan (offals). Namun, di Indonesia jeroan justru banyak dikonsumsi oleh masyarakat. Oleh karena itu, perlu diperiksa kesehataannnya untuk mencegah penularan penyakit. Pengawasan di Rumah Pemotongan Hewan (RPH) sebelum ternak dipotong (ante-mortem) dilakukan oleh instansi pemerintah setempat, bertujuan untuk menyeleksi dan memeriksa kesehatan semua hewan yang akan dipotong. Setelah hewan dipotong pengawasan dan pemeriksaan (postmortem), tetap dilakukan untuk memastikan apakah daging dan jeroannya sehat dan layak dikonsumsi (Direktorat Kesmavet, 2005).

Pada kenyataannya, dalam mata-rantai peredaran daging mulai dari produksi sampai ke tangan konsumen, tidak selalu mendapat pengawasan dan pemeriksaan.
Hal ini terjadi karena keterbatasan anggaran dan sumber daya manusia dari dinas terkait, sehingga daging yang dijual ke pasar kemungkinan tidak sehat dan membahayakan konsumen (Direktorat Kesmavet, 2005). Adanya keterbatasan dalam mendiagnosis suatu penyakit pada daging dan jeroan babi merupakan salah satu faktor penting lainnya. Oleh karena itu, diperlukan adanya penelitian untuk mendeteksi apakah ada penyakit yang bersifat zoonosis pada daging dan jeroan babi yang disembelih di Rumah Pemotongan Hewan setempat. Tujuan penelitian ini adalah untuk menganalisis kesehatan daging dan jeroan babi yang berpotensi menularkan penyakit zoonosis pada manusia yang diproduksi RPH Pesanggaran.

\section{METODE PENELITIAN}

\section{Rancangan Penelitian}

Penelitian ini menggunakan metode survei eksploratif kualitatif yaitu menganalisis sampel daging dan offals babi (paru, jantung, dan hati) produksi $\mathrm{RPH}$ Pesanggaran, Denpasar.

\section{Sampel Penelitian}

Jumlah sampel yang diambil setiap hari antara 8-11 ekor yang diperiksa secara inspeksi, palpasi, dan incici sesuai jenis kelamin (jantan dan betina) dan umur hewan (katagori muda dengan berat $<50 \mathrm{~kg}$ dan dewasa dengan berat $>$ dari $50 \mathrm{~kg}$ ). Total sampel penelitian yang diperiksa untuk daging, paru, hati, dan jantung sebanyak 100 sampel.

\section{Analisis Data}

Data hasil penelitian dianalisis secara deskriptif kualitaitf

\section{HASIL DAN PEMBAHASAN}

\section{Hasil}

Jumlah sampel daging dan jeroan babi yang diperiksa sebanyak 100 sampel terdiri atas 53 sampel babi betina dewasa (BD) dan 47 sampel babi jantan dewasa (JD). Tidak ditemukan sampel babi yang 
termasuk kategori muda (berat kurang dari $50 \mathrm{~kg}$ ) baik untuk babi betina maupun jantan. Seratus sampel babi yang diperiksa secara inspeksi, palpasi dan incici pada dagingnya tidak ditemukan adanya kelainan (100\% sehat), yaitu berwarna merah pucat, berbau darah, konsistensinya lembut. Paru babi yang sehat berwarna merah muda, bentuknya multilobularis, dan konsistensinya seperti spon/bunga karang. Hasil penelitian pada paru babi, menemukan nekrosis $15 \%$, pneumoni $30 \%$, kombinasi hemoragi dan pneumoni $5 \%$. Paru yang mengalami kelainan ini menunjukkan adanya perubahan warna menjadi abu-abu kehitaman atau merah. Jantung babi yang sehat berwarna cokelat, bentuk pada bagian apeksnya meruncing, dan konsistensinya kenyal/liat. Pada pemeriksaan jantung babi, ditemukan $13 \%$ hipertrofi/hiperplasi. Perubahan yang ditemukan pada jantung babi ini adalah konsistensinya sangat kenyal. Hati babi yang sehat berwarna cokelat, bentuknya multilobularis, dan konsistensinya padat elastis. Hasil penelitian menunjukkan 99\% hati babi sehat dan hanya $1 \%$ ditemukan mengandung larva sistiserkosis (Tabel 1 dan Gambar 1,2,3). Tidak ditemukan adanya cacing fasciola pada hati babi yang diperiksa ini, seperti yang sering dilaporkan ditemukan pada hati sapi (Mas-Coma et al., 2005; Pilet et al., 2010; Sripa et al., 2010). Hal ini karena pakan babi tidak pernah dikasi rumput seperti pakan sapi pada umumnya yang kadang berisi cercaria.
Berdasarkan jenis kelamin dan umur, paru babi yang mengalami nekrosis ditemukan sebanyak $15 \%$ terdiri atas $9 \%$ babi betina dewasa dan $6 \%$ babi jantan dewasa; pneumoni sebanyak $22 \%$ pada hewan betina dewasa dan $8 \%$ pada hewan jantan dewasa; kombinasi hemoragi dan pneumoni sebanyak 5\% ditemukan pada hewan betina dewasa $4 \%$ dan pada hewan jantan dewasa $1 \%$. Demikian pula pada jantung babi ditemukan sebanyak $87 \%$ sehat dan $13 \%$ mengalami kelainan hipertropi/hiperplasi yaitu pada babi betina dewasa $7 \%$ dan pada jantan dewasa $6 \%$. Pada organ hati ditemukan $99 \%$ sehat (layak dikonsusmsi), hanya $1 \%$ yang mengandung larva sistiserkus yaitu pada babi jantan dewasa. Kelainan pada organ paru babi lebih banyak pada babi betina dewasa daripada jantan dewasa, dan ada di antara kelainan tersebut yang berpotensi menularkan penyakit zoonosis pada manusia.

Paru babi yang dipotong di RPH Pesanggaran, Denpasar, $42 \%$ ditemukan mengalami kelainan pada babi betina dewasa dan $21 \%$ pada babi jantan dewasa. Jumlah paru yang mengalami kelainan ditemukan lebih banyak pada babi betina jika dibandingkan dengan babi jantan. Di antara kelainan yang ditemukan, pneumoni dan hemoragi atau kombinasi keduanya sangat berpotensi menularkan penyakit zoonosis kepada konsumen.

Tabel 1. Hasil Pemeriksaan Jeroan Babi

\begin{tabular}{llcccc}
\hline \multirow{2}{*}{ Jeroan } & \multirow{2}{*}{ Kelainan } & \multicolumn{2}{c}{ Babi betina } & \multicolumn{2}{c}{ Babi Jantan } \\
\cline { 2 - 5 } & & Muda & Dewasa & Muda & Dewasa \\
\hline \multirow{3}{*}{ Paru } & Nekrosis & 0 & 9 & 0 & 6 \\
& Pneumoni (P) & 0 & 22 & 0 & 8 \\
& Hemoragi (H) & 0 & 7 & 0 & 6 \\
\multirow{3}{*}{ Jantung } & Kombinasi (P\&H) & 0 & 4 & 0 & 1 \\
\multirow{3}{*}{ Hati } & Subtotal & 0 & 42 & 0 & 21 \\
& Hipertrofi/hiperplasi & 0 & 6 & 0 & 7 \\
& Subtotal & 0 & 6 & 0 & 7 \\
& Larva sistiserkus & 0 & 0 & 0 & 1 \\
& Subtotal & 0 & 0 & 0 & 1 \\
& Total & 0 & 48 & 0 & 29 \\
\hline
\end{tabular}




\section{Pembahasan}

Paru babi yang mengalami pneumoni dan hemoragi atau kombinasi keduanya, mengindikasikan babi tersebut terinfeksi oleh mikroorganisme, baik oleh bakteri ataupun virus). Penyakit bakteri yang dapat menimbulkan kelainan pada paru antara lain Colibacillosis, Salmonellosis (SE) dan Tuberculosis, sedangkan kelainan pada paru babi yang disebabkan oleh infeksi virus antara lain Hog cholera (Suardana dan Soejoedono, 2005). Di samping karena terinfeksi oleh mikroorganisme, kelainan pada paru babi juga dapat disebabkan oleh manajemen peternakan babi yang salah, misalnya sanitasi kandang yang buruk. Pada kondisi seperti ini penularan penyakit pada babi bisa karena inhalasi mikroba dari kandang, atau ingesti makanan yang terkontaminasi mikroba pada lantai kandang yang kotor (Ardana dan Haria Putra, 2010).

Kelainan pada jantung babi berupa hipertrofi/hiperplasi ditemukan sebanyak $6 \%$ pada babi betina dewasa dan $7 \%$ pada babi jantan dewasa. Jumlah kelainan jantung pada babi betina maupun babi jantan hampir sama. Kemungkinan kelainan pada jantung babi disebabkan oleh berbagai penyakit infeksi yang memaksa jantung harus berkontraksi lebih sering (frekuen) sehingga mengalami hipertrofi/hiperplasi. .Infeksi larva sisitiserkus pada hati babi dtemukan sebanyak $1 \%$ pada babi jantan dewasa. Kelainan ini disebabkan pakan atau minuman babi terkontaminasi oleh telur cacing pita (Taenia solium). Hal ini bisa terjadi jika manusia penderita Taeniasis (cacing pita) buang air besar di sungai, dan air sungai yang tercemar telur cacing pita ini terminum oleh babi (Damriyasa et al., 2000a,b; Dharmawan et al., 2012; Swacita et al., 2015). Temuan kelainan pada organ babi ini hampir serupa dengan organ sapi yang dilaporkan oleh Ester (2018) yang berasal dari RPH Pesanggaran, Denpasar. Hal ini mengindikasikan bahwa instansi terkait yang seyogyanya melakukan pemeriksaan dan pengawasan pada hewan yang akan disembelih tidak melakukan tugasnya dengan baik, sehingga jeroan babi yang mengalami kelainan dan berbahaya bagi konsumen lolos dari pemeriksaan dan pengawasan.Adanya temuan jeroan babi yang mengalami kelainan ini adalah sebagai signal agar personal RPH Pesanggaran lebih giat melakukan pemeriksaan dan pengawasan daging dan jeroan babi supaya konsumen tidak dirugikan (mengalami gangguan kesehatan).

\section{SIMPULAN DAN SARAN}

\section{Simpulan}

Seluruh daging babi produksi RPH Pesanggaran dalam keadaan sehat. Pada offals: paru ditemukan nekrosis $15 \%$, pneumoni $30 \%$ kombinasi pneumoni dan hemoragi $5 \%$. Pada jantung hipertropi/hiperplasi $13 \%$, dan pada hati ditemukan $1 \%$ berisi sistiserkus.

\section{Saran}

Penelitian ini bisa dilanjutkan dengan melakukan pemeriksaan laboratoris untuk menentukan diagnosis kelainan pada jeroan babi tersebut. Instansi terkait disarankan melakukan pengamanan dengan baik agar daging dan jeroan babi aman dan sehat untuk dikonsumsi masyarakat.

\section{UCAPAN TERIMA KASIH}

Terima kasih ditujukan kepada Rektor Unud atas bantuan dana DIPA PNBP melalui LPPM UNUD, Dekan FKH, Kepala Dinas Peternakan, Perikanan dan Kelautan Kota Denpasar, dan Kepala UPTD RPH Pesanggaran, Denpasar atas bantuan dan fasilitasnya untuk melakukan penelitian.

\section{DAFTAR PUSTAKA}

Agustina KK, Swacita IBN, Oka IBM, Dwinata IM, Traub RJ, Cargill C, Damriyasa IM. 2017. Reducing zoonotic and internal parasite burdens 
in pigs using a pig confinement system. Vet. World. 10(11): 1347-1352.

Ardana, IBK, Harya Putra IGK. 2008. Ternak Babi. Manajemen Reproduksi, Produksi, dan Penyakit. Edisi 1, Udayana University Press. Denpasar.

Damriyasa IM, Bauer C, Nockler K, Tenter AM, Sahner H. 2000a. Survey on zoonotic parasite infection $s$ in pigs in southern Bali, Indonesia. Proc. 19 Congress. DTSCH Ges. Parasitol. Stutgart.

Damriyasa IM, Edelhofer R, Volmer R, Bauer C, Sahner H. 2000b. Curreent Seroprevalence of Toxoplasma gondii infection in sows in two Region of Germany. Proc. $18^{\text {th }}$ Int. Conf. WAAVP, Stressa/Italy.

Dharmawan, NS, Swastika, K, Putra, IM, Wandra, T, Sutisna, P, Okamoto, M, and Ito, A. 2012. Present situationand problem of cysticercosis in animal in Bali and Papua. J. Vet. 13(2) : 154-162.

Direktorat Kesmavet. 2005. Pedoman Teknis Pemeriksaan Ante-mortem dan Post-mortem di Rumah Pemotongan Hewan. Ditjen Bina Produksi Peternakan, Deptan, Jakarta Pp. 1-16.

Ester, MA, Swacita, IBN, Suada, IK. 2018. Gambaran fisik pemeriksaan post- mortem organ jantung, paru-paru dan hati sapi bali yang berasal dari rumah pemotongan hewan Pesanggaran, Kota Denpasar. Indonesia Med. Vet. 7(2): 106-114.

Hadiwiyoto S. 1993. Teknologi hasil perikanan. ${ }^{\text {st }}$ Ed. Liberty. Yogyakarta.

Mas-Coma S, Bargues MD. Valero MA. 2005. Fasciolosis and other Plant-Borne Trematode Zoonosis. Int. J. Parasitol. $35: 1255-1265$

Pilet B. Deckers F, Pouillon M, Parizel B. 2010. Fasciola hepatica infection in a 65-year-old women. Radiol. Case. 4(4): 13-19.

Sripa, B, Kaewkes, S. Intapan, P.M. Maleewong, W. Brindly, P.J. 2010. Food borne trematodoasis in Southeast Asia: epidemiology, pathology, clinical manifestation an control. $A d v$. Parasitol. 72: 305-350.

Suardana IW, Soejoedono RR. 2005. Zoonosis. Edisi 1, Cetakan 1. Penerbit Universitas Udayana Press. Denpasar.

Swacita IBN, Damriyasa IM, Dharmawan NS, Astawa NM, Apsari IAP, Oka IBM, Tenaya IWM. 2015. Produksi dan Karakterisasi Antibodi Monoklonal Anti-Cysticercus cellulosae. J. Vet. 16(3): 325-333. 